\title{
LITERASI EKONOMI DALAM MEMBENTUK KEPRIBADIAN PRODUKTIF MAHASISWA PROGRAM MAGISTER PENDIDIKAN EKONOMI FKIP UNTAN
}

\author{
Nuraini Asriati, Universitas Tanjungpura \\ nuraini.asriati@fkip.untan.ac.id
}

\begin{abstract}
ABSTRAK
Masih terdapat beberapa mahasiswa yang memiliki literasi ekonomi yang belum memadai, sehingga belum mampu mengembangkan literasi ekonominya pada tataran analisis kritis terhadap permasalah ekonomi di masyarakat. Tujuan penelitian ini yakni mengkaji dan menganalisis kompetensi literasi ekonomi mahasiswa dalam pembentukan sikap produktif. Metode yang digunakan yakni kualitatif deskriptif dengan subjek penelitian yakni seluruh mahasiswa Magister Pendidikan konomi FKIP Universitas Tanjungpura yang berjumlah 25 mahasiswa. Temuan yang dihasilkan dalam penelitian ini yakni literasi ekonomi mahasiswa cukup memadai meskipun masih bersifat teoritif dan normatif. Literasi ekonomi tersebut menjadi dasar pembentukan kepribadian produktif mahasiswa sesuai bidang pekerjaan. Kepribadian produktif mahasiswapegawai, cenderung statis karena hanya rutinitas mengikuti sistem. Adapun kepribadian produktif mahasiswa-pengusaha cenderung dinamis karena menyesuaikan dengan kondisi perekonomian mutakhir.
\end{abstract}

Kata Kunci: Literasi Ekonomi, Kepribadian produktif, Pendidikan Ekonomi.

\section{ABSTRACT}

There are still some students who have inadequate economic literacy so that they have not developed their economic literacy at the level of critical analysis of economic problems in society. The purpose of this research is to study and analyze students' economic literacy competencies in the formation of productive attitudes. The method used is descriptive qualitative with the research subjects, namely all students of the Masters in Economic Education, FKIP Tanjungpura University, totaling 25 students. The findings made in this study are that students' economic literacy is quite adequate even though it is still theoretical and normative. This economic literacy is the basis for the formation of the productive personality of students according to their field of work. Productive student-employee personalities tend to be static because routines only follow the system. The student-entrepreneur productive personality tends to be dynamic because it adapts to the latest economic conditions.

Keywords: Economic Literacy, Productive Personality, Economic Education. 


\section{PENDAHULUAN}

Keberhasilan hidup seseorang pada dasarnya tergantung pada kecerdasan yang dimiliki. Kecerdasan tersebut terdiri dari kecerdasan emosional, kecerdasan intelektual, dan kecerdasan spiritual (Sina 2012). Orang yang memiliki kecerdasan intelektual yang optimal lebih dapat mentransfor-masikan situasi sulit, ia selalu peka terhadap peluang usaha dan mampu mengatasi permasalahan (Basrowi 2012). Adapun orang yang benarbenar optimal kecerdasan emosionalnya, lebih jeli dalam melihat peluang, lebih cekatan dalam bertindak, lebih punya inisiatif, dan memiliki kecakapan komunikasi (Hendarman and Tjakraatmadja 2012; Huston 2010). Individu tersebut lebih mampu mengatur strategi bisnis, memiliki kepekaan, daya cipta, dan komitmen yang tinggi. Kecerdasan intelektual dan emosional pada akhirnya akan membentuk perilaku individu yang mampu memanfaatkan kondisi diri dan lingkungan untuk meningkatkan nilai guna barang dan jasa yang dimiliki (Huston 2012). Tindakan ini mencerminkan bahwa individu tersebut memiliki kepribadian yang produktif. Pribadi yang produktif ialah individu yang menghasilkan kontribusi bermanfaat bagi lingkungannya (Hendarman and Tjakraatmadja 2012; Rao and Sreenivasan 2015).

Pengetahuan tentang kepribadian produktif semestinya dapat dipelajari dan dilatih oleh setiap mahasiswa pendidikan ekonomi pada saat mengikuti berbagai mata kuliah terutama yang berkaitan dengan ilmu ekonomi (Prastia, W, and Wardoyo 2017). Pada konteks ini, perguruan tinggi idealnya dapat mengasah keterampilan berfikir kritis mahasiswa berbasis literasi ekonomi yang dimiliki sehingga mampu membentuk kepribadian produktif di kalangan mahasiswa (Rasyid 2012; Ronto et al. 2017; Sulindawati and Musmini 2012). Literasi ekonomi yang komprehensif dan kepribadian produktif diharapkan dapat meningkatkan kesejahteraan masyarakat di tengah pergeseran ekonomi yang semakin cepat (Herawati 2015).

Pergeseran ekonomi industri menjadi ekonomi berbasiskan kompetensi manusia berimplikasi pada tuntutan atas kemampuan mengelola informasi guna membuat keputusan (Sina 2012). Informasi dan data berperan penting sebagai dasar pertimbangan yang cerdas dalam menggunakan uang dalam upaya memuaskan kebutuhan individu yang tidak terbatas dengan alat pemuas kebutuhan yang terbatas (Chinen and Endo 2012). Adapun literasi ekonomi yang komprehensif membuat mahasiswa mampu mengolah informasi yang begitu banyak dan cepat guna mengambil keputusan (Kanserina 2015; Pratiwi 2017). Implikasi keputusan ekonomi yang cerdas terindikasi dari kemampuan mengolah sumber daya yang dimiliki untuk menciptakan keuntungan ekonomis dan sosial bagi mahasiswa sebagai individu maupun sebagai bagian dari masyarakat sosial (Akmal and Saputra 2016; Altman 2012).

Literasi ekonomi diperoleh mahasiswa melalui proses pembelajaran di Perguruan Tinggi dalam bentuk kegiatan intra-kulikuler maupun ekstrakulikuler merupakan basis berifikir utama agar sesuai dengan standar rasionalitas ekonomi (Margaretha and Pambudhi 2015; Permata, Wahyono, and Wardoyo 2017). Begitu juga Attitude dan subjective norms berkontribusi terhadap pembelajaran dan pendidikan ekonomi keluarga (Syamsuri 2019). 
Berfikir dan bertindak sesuai dengan ukuran rasionalitas ekonomi merupakan suatu kondisi yang menggambarkan individu yang dapat memahami permasalahan dasar ekonomi secara baik, sehingga dapat melakukan kegiatan ekonomi dengan efektif dan efisien (Ibrahim and Alqaydi 2013; Pappalardo 2012). Literasi ekonomi menjadi pedoman bagi mahasiswa dalam menentukan skala prioritas barang dan jasa yang akan dibeli sehingga mahasiswa sebagai seorang konsumen mampu memilih berbagai macam alternatif barang dan jasa serta memiliki perencanaan di masa depan (Murdinar, Wahyono, and Haryono 2016; Nidar and Bestari 2012; Rooij, Lusardi, and Alessie 2011; Solihat and Arnasik 2018).

Selain memiliki kemampuan melakukan tindakan konsumtif berdasarkan standar rasionalitas ekonomi, literasi ekonomi yang dimiliki mahasiswa juga semestinya mampu mengarahkan mereka untuk berkepribadian produktif baik sebagai guru maupun pelaku ekonomi (Hasnawi 2015; Rozaini and Ginting 2019; Widyawati 2012). Sebagai guru, pengetahuan tentang ekonomi menjadi dasar pemilihan jenis produk pembelajaran yang dihasilkan, kuantitas produk serta segmentasi pemakai produk tersebut (Prasasti 2016; Sutikno 2009; Thomas 2013; Utami 2013). Adapun sebagai pelaku ekonomi, literasi yang baik akan membentuk pola pikir untuk dapat menentukan jenis komoditi yang akan dibuat, proses pembuatan komoditi dan segmentasi pemasarannya (Altman 2012; Santosa 2014; Sycheva et al. 2018).

Berdasarkan uraian di atas, maka mahasiswa Program Studi Magister Pendidikan Ekonomi FKIP Untan semestinya mampu menjadi pelaku, pendidik sekaligus penggerak kegiatan ekonomi yang berorientasi pada asasasas rasionalitas ekonomi. Kondisi normatif ini didasarkan pada asumsi bahwa mahasiswa magister pendidikan ekonomi seluruhnya sudah menyandang status Sarjana Pendidikan Ekonomi yang telah dibekali dengan berbagai ilmu dan konsep ekonomi selama menjalani perkuliahan strata satu (S-1), ditambah pendalaman teori pada level strata dua (S-2) yang sedang dijalani saat ini. Selain itu, mahasiswa magister pendidikan ekonomi FKIP Untan berasal dari latar pekerjaan yang beragam, mulai dari guru ekonomi, pengusaha, anggota Lembaga Swadaya Masyarakat dan beberapa pelaku ekonomi kreatif sehingga masing- masing mahasiswa telah memiliki wadah untuk mengaplikasikan ilmu yang diperoleh.

Namun demikian, fenomena di lapangan tidak sepenuhnya menunjukkan kondisi ideal seperti yang diasumsikan oleh peneliti. Masih terdapat beberapa mahasiswa yang memiliki literasi ekonomi yang belum memadai serta beberapa mahasiswa lain yang pengetahuannya masih pada tataran teoritis sehingga belum mampu mengembangkan literasi ekonominya pada tataran analisis kritis terhadap permasalah ekonomi di masyarakat. Fenomena ini peneliti buktikan dari hasil tes terhadap mahasiswa S-2 Pendidikan Ekonomi yang menunjukkan nilai rata-rata hanya 74,5 . Selain itu, peneliti juga sering mengajukan isu-isu mutakhir ekonomi sebagai bahan diskusi untuk mengetahui kemampuan analisa dan sintesa mahasiswa. Fenomena ini dikhawatirkan berdampak pada pembentukan kepribadian produksi mahasiswa dalam kehidupan sehari-hari baik sebagai guru maupun profesi lain yang mereka jalani. Berdasarkan hasil tes dan observasi selama perkuliahan tersebut, peneliti tertarik untuk mengkaji lebih lanjut tentang literasi ekonomi pada mahasiswa 
serta peran literasi ekonomi tersebut dalam membentuk kepribadian produktif mereka.

Fokus dan tujuan penelitian ini yakni melakukan kajian tentang literasi ekonomi dalam membentuk kepribadian produktif mahasiswa Program Magister Pendidikan Ekonomi FKIP Untan. Hasil kajian ini dapat menjadi dasar evaluasi terhadap efektivitas proses perkuliahan yang selama ini berlangsung, mecakup efektivitas kurikulum, media serta metode pengajaran.

Beberapa hasil penelitian relevan tentang literasi ekonomi yang menjadi acuan empiris yakni riset Herawati yang menemukan bahwa bahwa pembelajaran di perguruan tinggi tidak berkontribusi secara signifikan terhadap perilaku keuangan mahasiswa. Literasi keuangan berkontribusi positif dan signifikan terhadap perilaku keuangan mahasiswa. Adapun fenomena di tempat peneliti bertentangan dengan penelitian yang menyatakan bahwa secara simultan pembelajaran di perguruan tinggi dan literasi keuangan berkontribusi secara signifkan terhadap perilaku keuangan mahasiswa (Herawati, 2015). Sejalan dengan kajian tersebut, penelitian Sabri and MacDonald (2010) pada mahasiswa di Malaysia bahwa tindakan ekonomi mahasiswa justru dipengaruhi oleh lingkungan masa lalu sebelum kuliah dan lingkungan sosial yang membentuk perilaku pengelolaan keuangan mahasiswa. Temuan ini sejalan dengan asumsi awal peneliti bahwa literasi ekonomi mahasiswa sebagai subjek penelitian dibentuk dari pengetahuan awal yang mereka dapat serta lingkungan tempat mereka bekerja, namun demikian asumsi ini masih perlu dibuktikan.

Adapun fenoma di tempat penelitian yang sejalan dengan penelitian terdahulu yakni hasil penelitian Margaretha dan Pambudhi juga menyatakan bahwa tingkat literasi keuangan mahasiwa hanya 48,91\% dengan kategori cukup rendah. Tingkat literasi ini dipengaruhi oleh jenis kelamin, usia, IPK, dan penghasilan orang tua. Kesimpulannya, mahasiswa belajar secara mandiri dan melakukan improvisasi dalam mengelola investasi keuangannya (Margaretha and Pambudhi 2015). Sejalan dengan temuan ini, Rasyid yang menyatakan bahwa kemampuan manajemen keuangan mahasiswa berada pada level menengah dan terdapat sumbangan pengaruh literasi ekonomi terhadap kemampuan manajemen keuangan tersebut (Rasyid 2012).

Hasil riset Solihat dan Arnasik menyatakan bahwa literasi ekonomi berkontribusi positif terhadap perilaku konsumtif mahasiswa. Hal ini berarti semakin tinggi tingkat literasi ekonomi mahasiswa maka tindakan ekonomi mereka semakin rasional (Solihat \& Arnasik, 2018). Temuan ini juga bertentangan dengan kondisi di tempat penelitian yang menunjukkan kecenderungan yang terjadi bahwa responden yang semuanya telah menyelesaikan pendidikan strata satu dan telah memiliki penghasilan justru tingkat literasi ekonomi masih belum memadai, seperti yang dikemukakan oleh Susanti bahwa Lotus of Control Internal memiliki pengaruh positif terhadap literasi ekonomi mahasiswa dan tingkat pendapatan memiliki pengaruh negatif. Hal ini mengindikasikan bahwa semakin tinggi Lotus of Control Internal maka literasi ekonomi mahasiswa juga semakin tinggi, sebaliknya semakin tinggi pendapatan maka literasi ekonomi mahasiswa semakin rendah (Susanti 2017).

Adapun beberapa riset tentang kepribadian produktif yang menjadi kajian empiris yakni penelitian Prasasti menyatakan bahwa hasil penelitian menunjukkan bahwa terdapat pengaruh positif yang signifikan antara 
kepemimpinan kepala sekolah, kompetensi guru, dan lingkungan kerja terhadap kepribadian produktif sekolah secara simultan maupun parsial. Variabel bebas memiliki pengaruh terhadap kepribadian produktif sekolah sebesar 57,30\%, sisanya 42,70\% dipengaruhi faktor lain di luar model. Faktor yang paling dominan mempengaruhi kepribadian produktif sekolah adalah kompetensi guru (Prasasti 2016). Kaitan hasil penelitian ini dengan topik penelitian yang disajikan yakni responden penelitian sebagian besar adalah guru mata pelajaran ekonomi sehingga memliki kompetensi yang memadai. Hasil penelitian Prasasti tersebut perlu dijadikan landasan empiris guna membuktikan bahwa komptensi responden sebagai guru ekonomi di sekolah berkontribusi terhadap kepribadian produktif mereka. Selain itu, responden yang telah memiliki kemampuang dalam mengelola teknologi semestinya memiliki kepribadian produktif yang lebih baik meskipun hasil penelitian Mačiulytė-Šniukienė dan Gaile-Sarkane menyatakan bahwa faktor informasi dan teknologi ternyata tidak memberikan dampak yang signifikan terhadap kepribadian produktif karyawan melainkan karena berbagai faktor lain yang tidak dimasukkan dalam penelitian (Mačiulytė-Šniukienè and Gaile-Sarkane 2014).

Pada konteks perguruan tinggi, hasil penelitian tentang kepribadian produktif mahasiswa dilakukan oleh Prastia, Mintarti dan Wardoyo tentang berbagai faktor kepribadian produktif mahasiswa ekonomi bahwa finansial literasi tidak berpengaruh terhadap self efficacy, dan rasionalitas ekonomi berpengaruh terhadap self efficacy. Self efficacy berpengaruh terhadap kepribadian produktif. Pendidikan ekonomi di keluarga berpengaruh terhadap kepribadian produktif, financial literracy juga berpengaruh terhadap kepribadian produktif. Rasionalitas ekonomi berpengaruh terhadap perilaku produktif. Pendidikan Ekonomi di keluarga tidak berpengaruh terhadap kepribadian produktif melalui self efficacy. Finansial literasi tidak berpengaruh terhadap kepribadian produktif melalui self efficacy, rasionalitas ekonomi berpengaruh terhadap kepribadian produktif melalui self efficacy (Prastia et al. 2017). Penelitian lain yang senada juga dipublikasikan oleh Sulindawati dan Musmini bahwa (1) terdapat perbedaan kemampuan berpikir produktif antara mahasiswa yang belajar dengan asesmen portofolio dan yang belajar dengan asesmen konvensional, (2) terdapat perbedaan kemampuan berpikir produktif antara mahasiswa yang memiliki gaya kognitif field dependent dan field independent, (3) tidak terdapat interaksi antara asesmen dan gaya kognitif mahasiswa terhadap kemampuan berpikir produktif (Sulindawati and Musmini 2012). Temuan dalam penelitian ini sangat berkaitan dan penting untuk dijadikan landasan empiris karena kesamaan subjek dan topik penelitian sehingga nantinya peneliti dapat membandingkan temuan di lapangan dengan hasil penelitian yang terdahulu.

Berdasarkan uraian tentang beberapa kajian terdahulu yang dianggap relevan tentang literasi ekonomi dan kepribadian produktif, maka nilai kebaruan (novelty) dalam penelitian ini yakni peneliti melakukan analisis terhadap objek kajian berupa literasi ekonomi pada masiswa Magister Pendidikan Ekonomi yang diasumsikan sebagai individu yang memiliki level pendidikan di atas sarjana dengan berbagai profesi yang mereka jalani, dan 
kontribusi literasi ekonomi tersebut dalam pembentukan kepribadian produktif mereka.

\section{METODE PENELITIAN}

Metode penelitian yang digunakan yakni kualitatif deskriptif. Pendekatan kualitatif dipilih karena alasan berikut: (1) realitas yang ada pada dasarnya bersifat ganda, terkonstruksi dan holistik; (2) antara orang yang mengetahui dan diketahui bersifat interaktif dan tidak dapat dipisahkan; (3) hanya waktu dan konteks yang memungkinkan berkaitan dengan hipotesis kerja; (4) semua entitas yang ada dalam kondisi yang saling simultan sehingga tidak mungkin membedakan sebab-akibat; (5) penelitian pada dasarnya bebas dari nilai (Basri 2011). Pada konteks penelitian ini, maka peneliti bermaksud mengkaji literasi ekonomi mahasiswa dan perannya dalam pembentukan kepribadian positif tanpa mencari tingkat hubungan yang terukur secara matematis. Instrumen yang digunakan peneliti yakni pedoman wawancara sehingga peneliti memperoleh informasi yang mendalam terkait objek penelitian, instrument tes guna mengetahui tingkat literasi ekonomi pada mahasiswa serta lembar observasi untuk mengamati kepribadian produktif mahasiswa saat di kelas (Sugiyono 2011). Subjek penelitian ini yakni seluruh mahasiswa Program Studi Pendidikan Ekonomi FKIP Universitas Tanjungpura angkatan 2014, 2015 dan 2016 yang berjumlah 25 orang. Alasan penetapan subjek penelitian karena jumlah seluruh mahasiswa masih terjangkau untuk dilakukan penelitian.

Fokus penelitian ini pada aspek literasi ekonomi dan kepribadian produktif. Literasi ekonomi dapat dimaknai sebagai dasar pengetahuan sebagai alat untuk lebih cerdas dalam mengambil keputusan ekonomi (Sina, 2012). aspek literasi ekonomi yang akan dikaji yakni 1) Pengetahuan tentang konsep keuangan 2) Kemampuan untuk berkomunikasi tentang konsep keuangan 3) Kemampuan untuk mengelola keuangan pribadi 4) Kemampuan dalam membuat keputusan keuangan 5) Keyakinan untuk membuat perencanaan keuangan masa depan (Margaretha and Pambudhi 2015). Adapun kepribadian produktif dapat dimaknai sebagai kegiatan atau aktifitas manusia dalam menghasilkan, memberi hasil, manfaat pada diri dan lingkungannya (Murdinar et al. 2016).

Semua informasi yang diperoleh melalui proses wawancara dianalisa menggunakan pendekatan Miles and Hubberman yakni reduksi data, penyajian data, dan penarikan kesimpulan (Sugiyono 2011). Pada tahap reduksi data, informasi yang dikumpulkan dikelompokkan berdasarkan kategori informasi guna mempermudah analisa selanjutnya. Informasi yang telah direduksi kemudian disajikan sehingga nampak perbedaan kategori antar kelompok informasi. Tahap terakhir yakni penarikan kesimpulan sebagai hasil analisa terhadap informasi yang disajikan.

\section{HASIL PENELITIAN DAN PEMBAHASAN}

\section{Literasi Ekonomi}

Literasi ekonomi dapat dipahami sebagai pengetahuan dasar yang dimiliki oleh seseorang untuk mengambil keputusan dalam aspek kegiatan 
ekonomi. Oleh karena itu, upaya menanamkan dan meningkatkan literasi ekonomi harus dilakukan secara terencana dan sistematis dalam proses pembelajaran informal, formal maupun nonformal. Proses pembelajaran ekonomi yang efektif akan berdampak pada penambahan aset, pengelolaan keuangan yang tepat, proteksi, peningkatan tabungan dan kepribadian produktif ekonomi.

Hasil wawancara dengan seluruh responden terkait aspek-aspek literasi ekonomi yang telah direduksi, dapat disajikan sebagai berikut. Pada aspek pengetahuan tentang konsep keuangan, responden memahami dengan baik tentang manajemen keuangan yang baik berdasarkan teori yang mereka pelajari. Responden dapat menjawab dengan baik pertanyaan tentang manajemen keuangan yang meliputi pendapatan, konsumsi dan tabungan dari hasil pekerjaan mereka. Responden sepenuhnya menyadari bahwa seluruh pendapatan mereka harus dialokasikan secara tepat sesuai skala prioritas. Pada aspek kemampuan untuk berkomunikasi tentang konsep keuangan, mahasiswa yang berprofesi sebagai tenaga pendidik memiliki kemampuan menyampaikan informasi tentang konsep keuangan secara lebih baik daripada mahasiswa yang bekerja sebagai pengusaha mapuan pegawai non- pendidik. Pernyataan ini diperoleh berdasarkan hasil pengamatan selama proses wawancara berlangsung, yakni mahasiswa yang berprofesi sebagai guru menyampaikan informasi secara runtut dengan dasar teori. Pada aspek kemampuan untuk mengelola keuangan pribadi, peneliti dapat menyatakan bahwa mahasiswa yang memiliki usaha memiliki kemampuan yang lebih baik daripada mahasiswa yang menjadi pegawai. Berdasarkan hasil wawancara, mahasiswa yang memiliki usaha secara konsisten membuat alokasi keuangan dan mencatat seluruh transaksi keuangan pribadi mereka agar tidak bercampur dengan keuangan usaha.

Aspek literasi ekonomi yang menjadi topik pertanyaan selanjutnya yakni mengenai kemampuan mahasiswa dalam membuat keputusan keuangan. Sejalan dengan aspek sebelumya, mahasiswa Magister Pendidikan Ekonomi yang menjadi pengusaha mampu menunjukkan bahwa mereka mampu membuat keputusan keuangan secara lebih rasional dan terukur. Mahasiswa sekaligus pengusaha sepenuhnya meyakini bahwa pengambilan keputusan yang salah dapat berakibat pada kerugian usaha mereka. Adapun mahasiswa yang bekerja sebagai pegawai, menunjukkan perilaku pengambilan keputusan yang kurang rasional. Hasil wawancara secara implisit menyatakan bahwa mahasiswa- pegawai lebih banyak membuat keputusan ekonomi secara spontan dan pembelian barang atau jasa secara tidak terencana (ipulsive buying). Keputusan yang spontan ini juga didasari keyakinan bahwa mereka akan memperoleh penghasilan secara tetap setiap bulan. Aspek literasi ekonomi yang terakhir yakni keyakinan untuk membuat perencanaan keuangan masa depan. Pada aspek ini seluruh responden meyakini bahwa mereka harus membuat perencanaan keuangan di masa depan, meskipun hasil wawancara secara implisit menyatan terdapat perbedaan konsep antara mahasiswapengusaha dengan mahasiswa-pegawai. Mahasiswa-pengusaha membuat rencana keuangan masa depan secara mandiri dengan memperhitungkan nilai asset yang mereka investasikan sekarang dengan perkembangan asset tersebut di masa depan. Adapun mahasiswa-pegawai menitikberatkan pada 
penghasilan tetap mereka setelah pensiun. Hasil penelitian ini sejalan dengan beberapa penelitian terdahulu yang menjadi landasan empiris dalam penelitian (Herawati 2015; Margaretha and Pambudhi 2015; Rasyid 2012; Sabri and MacDonald 2010; Solihat and Arnasik 2018; Susanti 2017).

Berdasarkan hasil penyajian informasi tentang aspek-aspek literasi ekonomi, dapat dinyatakan bahwa pengetahuan ekonomi yang baik akan berdampak pada pola perilaku ekonomi. Literasi ekonomi mahasiswa yang diperoleh dari pembelajaran di Perguruan Tinggi atau dari pengalaman dan lingkunga sekitar, menjadi dasar pembuatan keputusan ekonomi masingmasing individu. Perilaku ekonomi baik dalam hal memproduksi, mendistribusi maupun mengkonsumsi barang, jika dilandasi dengan pengetahuan yang memadai dapat membuat individu mengambil keputusan secara efektif dan efisien. Sebaliknya, semua keputusan yang dilakukan tanpa didasari pengetahuan yang memadai tentang ilmu ekonomi hanya akan mengakibatkan inefisiensi dan inefektivitas sumber daya yang telah dikorbankan untuk mendapatkan maupun menghasilkan barang atau jasa. Pernyataan ini mendukung hasil penelitian yang menyatakan bahwa literasi ekonomi memiliki pengaruh terhadap perilaku ekonomi (Altman 2012; Margaretha and Pambudhi 2015; Murniatiningsih 2017; Pratiwi 2017; Rooij et al. 2011; Rozaini and Ginting 2019; Solihat and Arnasik 2018; Susanti 2017).

\section{Kepribadian produktif}

Perilaku ekonomi yang didasari pada pengetahuan yang memadai sangat penting dikuasai oleh para mahasiswa magister pendidikan ekonomi terutama kaitannya terhadap kepribadian produktif. Secara normatif, mahasiswa pascasarjana diyakini telah memiliki bekal pengetahuan ekonomi yang layak sebagai hasil proses pembelajaran di tingkat Strata satu (S-1) sehingga semestinya mampu mengambil keputusan-keputusan tindakan produktif yang tepat. Selain itu, mahasiswa pascasarjana diyakini telah memiliki pengalaman yang cukup tentang tindakan ekonomi serta konsekuensi yang menyertai tindakan tersebut.

Berdasarkan hasil penelitian yang dilakukan terhadap mahasiswa Magister Pendidikan Ekonomi di FKIP Universitas Tanjungpura, diketahui bahwa tingkat pengetahuan dasar ekonomi yang dimiliki mahasiswa pascasarjana cukup baik. Namun demikian, tidak seluruh responden mampu mengaplikasikan pengetahuan tentang ekonomi tersebut dalam kepribadian produktif sehari-hari. Hasil wawancara secara mendalam secara implisit menunjukkan bahwa mahasiswa Magister Pendidikan ekonomi yang tidak bekerja sebagai pegawai memiliki kepribadian produktif secara ekonomi yang lebih baik. Adapun mahasiswa yang bekerja sebagai pegawai baik tenaga pendidik maupun non-pendidik, kepribadian produktif yang ditunjukkan lebih utama pada beban kerja (job description) yang melekat pada status kepegawaian mereka. Kepribadian produktif mahasiswa-pegawai cenderung statis dalam bentuk rutinitas kerja mengikuti sistem yang berlaku. Pernyataan ini mendukung hasil penelitian sebelumnya tentang kepribadian produktif pengawai (Mačiulytė-Šniukienė and Gaile-Sarkane 2014; Prasasti 2016; Prastia et al. 2017; Sulindawati and Musmini 2012). 


\section{Literasi Ekonomi dalam Membentuk Kepribadian produktif}

Beberapa konsep yang dapat peneliti rumuskan tentang perbedaan kepribadian produktif pada mahasiswa magister Pendidikan Ekonomi FKIP Untan, meskipun mendapatkan proses pembelajaran ekonomi yang memadai, yakni sebagai berikut. Pertama, perbedaan cara mahasiswa pascasarjana untuk mengulang materi yang telah diperoleh setelah selesai menjalani perkuliahan. Mahasiswa yang berprofesi sebagai guru, mengulang kembali materi tersebut dalam proses pembelajaran di kelas saat mengajar. Adapun mahasiswa yang tidak berkerja sebagai guru, hanya mengulang materi saat akan menghadapi ujian semester. Sedangkan mahasiswa yang memiliki usaha, mengulang materi dalam kepribadian produktif menjalankan usahanya. Kedua, perbedaan minat membaca dan menambah kemampuan secara mandiri sebagai upaya mengembangkan materi yang diperoleh. Mahasiswa yang berprofesi sebagai guru lebih produktif dalam menambah pengetahuan secara mandiri karena tuntutan profesi untuk selalu menambah pengetahuan dan mengembangkan materi sebagai bahan ajar di kelas. Mahasiswa yang bekerja sebagai pegawai non-pendidik, cenderung kurang aktif dalam menambah kemampuan mandiri sehingga pengetahuan yang dimiliki hanya yang diajarkan dosen di kelas. Adapun mahasiswa yang mengelola usaha, penambahan pengetahuan diperoleh melalui pengalaman dalam mengelola usaha dan interaksi dengan mitra usaha. Ketiga, perbedaan kemampuan berfikir logis dan daya analisis mahasiswa pascasarjana. Mahasiswa yang berprofesi sebagai guru dan pengusaha lebih mampu menyesuaikan materi yang diperoleh di Perguruan Tinggi dengan fenomena yang ditemui di lembaga tempat bekerja maupun isu-isu ekonomi mutakhir di masyarakat. Kemampuan apersepsi materi ini mendorong kepribadian produktif mahasiswa dalam menjalani pekerjaan maupun mengelola usaha.

Hasil kajian terhadap informasi yang diperoleh melalui proses wawancara menunjukkan bahwa aspek kompetensi kognitif literasi ekonomi mahasiswa masih dominan bersifat teoritif-normative karena sebagian besar bekeja sebagai guru dan pengawai non-pendidik. Adapun aspek substantiveapllikatif lebih dimiliki oleh mahasiswa yang mengelola usaha karena lebih produktif dalam mengelola usaha. Temuan ini menunjukkan bahwa literasi ekonomi mahasiswa memiliki peran dalam membentuk kepribadian produktif sesuai dengan bidang perkejaan masing-masing.

\section{SIMPULAN}

Simpulan yang dapat dinyatakan dari hasil kajian terhadap fokus penelitian yakni literasi ekonomi mahasiswa Magister Pendidikan Ekonomi FKIP Universitas Tanjungpura mayoritas cenderung pada tataran pengetahuan teoritis. Literasi ekonomi ini memiliki peran dalam membentuk kepribadian produktif mahasiswa sesuai bidang pekerjaan masing-masing. Rekomendasi yang dapat disampaikan berdasarkan hasil penelitian ditujukan kepada mahasiswa Magister Pendidikan Ekonomi, hendaknya lebih aktif dalam meningkatkan literasi ekonomi dan pola kepribadian produktif sehingga mampu berperan aktif pada upaya perbaikan kesejahteraan ekonomi masyarakat. 


\section{DAFTAR RUJUKAN}

Akmal, Huriyatul and Yogi Eka Saputra. 2016. "Analisis Tingkat Literasi Keuangan.” Jurnal Ekonomi Dan Bisnis Islam 1(2):235-44.

Altman, Morris. 2012. "Implications of Behavioural Economics for Financial Literacy and Public Policy.” The Journal of Socio-Economics 41(5):67790 .

Basri, Muhammad. 2011. "Internalization of Attitudes and Intention in the Morality of Students of Economics Faculty of Economics Education Program State University of Malang." Malang University.

Basrowi. 2012. Kewirausahaan Untuk Perguruan Tinggi. Ghalia Indonesia.

Chinen, Kenichiro and Hideki Endo. 2012. "Effects of Attitude and Background on Personal Financial Ability: A Student Survey in the United States." International Journal of Management 29(2):778-91.

Hasnawi, Fahri. 2015. "Pemberdayaan Dosen Fakultas Ekonomi Untuk Meningkatkan Produktivitas Kerja Melalui Kerjasama Dengan Stakeholder Di Kota Medan.” JURNAL Pengabdian Kepada Masyarakat 21:73-77.

Hendarman, Achmad Fajar and Jann Hidajat Tjakraatmadja. 2012. "Relationship among Soft Skills, Hard Skills, and Innovativeness of Knowledge Workers in the Knowledge Economy Era." Procedia - Social and Behavioral Sciences 52:35-44.

Herawati, Nyoman Trisna. 2015. "Kontribusi Pembelajaran Di Perguruan Tinggi Dan Literasi Keuangan Terhadap Perilaku Keuangan Mahasiswa." Jural Pendidikan Dan Pengajaran 1-3(48):60-70.

Huston, Sandra J. 2010. "Measuring Financial Literacy." The Journal Of Consumer Affairs 44(2):296-319.

Huston, Sandra J. 2012. "Financial Literacy and the Cost of Borrowing." International Journal of Consumer Studies 36(5):566-72.

Ibrahim, Mohamed E. and Fatima R. Alqaydi. 2013. "Financial Literacy, Personal Financial Attitude, and Forms of Personal Debt among Residents of the UAE." International Journal of Economics and Finance $5(7)$.

Kanserina, Dias. 2015. "Perilaku Konsumtif Mahasiswa Jurusan Pendidikan Ekonomi UNDIKSHA 2015.” Jurnal Pendidikan Ekonomi Undiksha $5(1)$. 
Mačiulytė-Šniukienė, Alma and Elina Gaile-Sarkane. 2014. "Impact of Information and Telecommunication Technologies Development on Labour Productivity." Procedia - Social and Behavioral Sciences 110:1271-82.

Margaretha, Farah and Reza Arief Pambudhi. 2015. "Tingkat Literasi Keuangan Pada Mahasiswa S-1 Fakultas Ekonomi." Jurnal Manajemen Dan Kewirausahaan (Journal of Management and Entrepreneurship) 17(1):76-85.

Murdinar, Hardining Estu, Hari Wahyono, and Agung Haryono. 2016. "Pembelajaran Ekonomi Untuk Meningkatkan Perilaku Produktif Siswa SMA.” Pp. 543-55 in National Conference of Education.

Murniatiningsih, Endah. 2017. "Pengaruh Literasi Ekonomi Siswa, Hasil Belajar Ekonomi, Dan Teman Sebaya Terhadap Perilaku Konsumsi Siswa SMP Negeri Di Surabaya Barat." Jurnal Ekonomi Pendidikan Dan Kewirausahaan 5(1):127-56.

Nidar, Sulaeman Rahman and Sandi Bestari. 2012. "Personal Financial Literacy Among University Students (Case Study at Padjadjaran University Students , Bandung, Indonesia)." World Journal of Social Sciences 2(4):162-71.

Pappalardo, Janis K. 2012. "Product Literacy and the Economics of Consumer Protection Policy." Journal of Consumer Affairs 46(2):319-32.

Permata, Bayu, Hari Wahyono, and Cipto Wardoyo. 2017. "Bahan Ajar Berbasis Cerita Untuk Menanamkan Literasi Ekonomi Pada Siswa Sekolah Dasar." Jurnal Pendidikan: Teori, Penelitian, Dan Pengembangan 2(3):356-62.

Prasasti, Anita. 2016. "Pengaruh Kepemimpinan Kepala Sekolah, Kompetensi Guru, Dan Lingkungan Kerja Terhadap Produktivitas Sekolah.” Journal of Accounting and Business Education 2(2).

Prastia, Rheza Hafid, Sri Umi Mintarti W, and Cipto Wardoyo. 2017. "FaktorFaktor Yang Memengaruhi Perilaku Produktif Mahasiswa Fakultas Ekonomi Angkatan Tahun 2013." Jurnal Pendidikan: Teori, Penelitian, Dan Pengembangan 2(2):238-45.

Pratiwi, Indah. 2017. "Pengaruh Literasi Ekonomi, Kelompok Teman Sebaya Dan Kontrol Diri Terhadap Perilaku Pembelian Impulsif Untuk Produk Fashion Di Online Shop Pada Mahasiswa Jurusan Pendidikan Ekonomi UNDIKSHA.” Jurnal Pendidikan Ekonomi Undiksha 9(1):98-108. 
Rao, B. Prakash Rao and Ambika Sreenivasan. 2015. "Factors Affecting Labor Productivity in Bangalore." International Journal of Engineering Research And V4(04).

Rasyid, Rosyeni. 2012. "Analisis Tingkat Literasi Keuangan Mahasiswa Program Studi Manajemen Fakultas Ekonomi Universitas Negeri Padang." Jurnal Kajian Manajemen Bisnis 1(2):91-106.

Ronto, Rimante, Lauren Ball, Donna Pendergast, and Neil Harris. 2017. "Environmental Factors of Food Literacy in Australian High Schools: Views of Home Economics Teachers." International Journal of Consumer Studies 41(1):19-27.

Rooij, Maarten C. J. van, Annamaria Lusardi, and Rob J. M. Alessie. 2011. "Financial Literacy and Retirement Planning in the Netherlands." Journal of Economic Psychology 32(4):593-608.

Rozaini, Noni and Bismi Aditya Ginting. 2019. "Pengaruh Literasi Ekonomi Dan Kontrol Diri Terhadap Perilaku Pembelian Impulsif Untuk Produk Fashion." NIAGAWAN 8(1):1-9.

Sabri, Mohamad Fazli and Maurice MacDonald. 2010. "Savings Behavior and Financial Problems among College Students: The Role of Financial Literacy in Malaysia | Sabri | Cross-Cultural Communication." Crosscultural Communication 6(3):P103-110.

Santosa, Imam. 2014. "Masalah Dan Tantangan Pengembangan Kewirausahaan Pada Kalangan Mahasiswa Di Indonesia." AJIE 3(3):203-7.

Sina, Peter Garlans. 2012. "Analisis Literasi Ekonomi." Jurnal Economia $8(2): 135-43$.

Solihat, Ai Nur and Syamsudin Arnasik. 2018. "Pengaruh Literasi Ekonomi Terhadap Perilaku Konsumtif Mahasiswa Jurusan Pendidikan Ekonomi Universitas Siliwangi." OIKOS Jurnal Kajian Pendidikan Ekonomi Dan Ilmu Ekonomi 2(1):1-13.

Sugiyono. 2011. Metode Penelitian Kuantitatif Kualitatif Dan R\&D. 14th ed. Bandung: Alfabeta.

Sulindawati, Ni Luh Gede Erni and Lucy Sri Musmini. 2012. "Pengaruh Asesmen Portofolio Dan Gaya Kognitif Terhadap Kemampuan Berpikir Produktif Mahasiswa." Jurnal Pendidikan Dan Pengajaran 45(2):99109. 
Susanti, Susanti. 2017. "Pengaruh Locus of Control Internal Dan Pendapatan Terhadap Literasi Keuangan Mahasiswa." Jurnal Ekonomi Pendidikan Dan Kewirausahaan 4(1):5.

Sutikno, Tri Atmadji. 2009. "Indikator Produktivitas Kerja Guru Sekolah Menengah Kejuruan." Indikator Produktivitas Kerja Guru Sekolah Menengah Kejuruan 32(1):107-19.

Syamsuri. 2019. "Analisis Konsep Theory of Planned Behavior Terhadap Pembelajaran Wirausaha Dan Pendidikan Ekonomi Keluarga Pelaku UMKM." Jurnal PROFIT: Kajian Pendidikan Ekonomi Dan Ilmu Ekonomi 6(2):101-13.

Sycheva, I. N., E. M. Akhmetshin, A. N. Dunets, I. A. Svistula, T. A. Panteleeva, and I. Yu Potashova. 2018. "Labour Relations in Research of Socio-Economic Systems." European Research Studies Journal 21(4):356-67.

Thomas, Partono. 2013. "Faktor Determinan Produktivitas Sekolah.” Jurnal Penelitian Dan Evaluasi Pendidikan 17(1):55-71.

Utami, Athika Dwi Wiji. 2013. "Faktor-Faktor Determinan Profesionalisme Guru SMK Bidang Keahlian Teknologi Informasi Dan Komunikasi.” Jurnal Pendidikan Vokasi 2(2):169-82.

Widyawati, Irin. 2012. "Faktor-Faktor Yang Mempengaruhi Literasi Finansial Mahasiswa Fakultas Ekonomi Dan Bisnis Universitas Brawijaya." Assets: Jurnal Akuntansi Dan Pendidikan 1(1):89. 
